\title{
Viability of The Isolated Yersinia enterocolitica Strains from Damietta Cheese and Ice Cream at Different Refrigeration and Freezing Temperatures
}

\author{
Salwa S.Thabet ${ }^{1}$ and Manal H.Thabet ${ }^{2 *}$ \\ ${ }^{1}$ Dept. of Food Hygiene, Animal Health Research Institute (Regional Laboratory, Assiut), Agriculture Research \\ Center (ARC), Egypt. \\ ${ }^{2}$ Dept. of Bacteriology, Animal Health Research Institute (Regional Laboratory, Assiut), Agriculture Research \\ Center (ARC), Egypt. \\ *Corresponding Author, Manal H.Thabet, E-mail: a2m_2050@yahoo.com
}

\begin{abstract}
Yersinia enterocolitica is considered one of the most prevalent pathogens transmitted through milk and milk products. Therefore, we aimed to detect the prevalence of these bacteria in cheese and ice cream and study the influence of refrigeration and freezing on its growth patterns. A total of 80 samples of cheese and ice cream were collected from Assiut city, Egypt (40 samples each). The collected samples were examined for the isolation of $Y$. enterocolitica by the classical culture method and improved by the PCR technique. The incidence of $Y$. enterocolitica was 17.5 and $25.0 \%$ in the examined cheese and ice cream samples by culture method, respectively, its prevalence in the tested cheese and ice cream samples basing on PCR were 7.5 and $15 \%$ since 42.8 and $60.0 \%$ of the isolated $Y$. enterocolotica were confirmed positive. Bio- typing and serotyping of the isolated strains revealed that 8 out of the confirmed strains were pathogenic ; Y. enterocolitica serotype O: 3 was the most prevalent strain, and all of the pathogenic strains carried the virulent ail gene. Nearly similar growth patterns of $Y$. enterocolitica were recorded during storage of cheese at $4 \pm 2^{\circ} \mathrm{C}$ and $30 \pm 2^{\circ} \mathrm{C}$ and, a significant difference was observed in the $3^{\text {rd }}$ week, the organism found to be survived for 18 weeks with a mean value of $7.4 \pm 0.5$ and $6.9 \pm 0.16 \mathrm{log} \mathrm{cfu} / \mathrm{g}$ for cheese stored at $4 \pm 2{ }^{\circ} \mathrm{C}$ and $30 \pm 2{ }^{\circ} \mathrm{C}$ respectively. In the case of ice cream, there was a significant difference between the behavior of $Y$. enterocolitica during freezing storage at $-6 \pm 2^{\circ} \mathrm{C}$ and $-18 \pm 2^{\circ} \mathrm{C}$ in the $2^{\text {nd }}$ week, the mean value for the organism count on the $16^{\text {th }}$ week was $5.3 \pm 0.26$ and $5.6 \pm 0.39$ $\log \mathrm{cfu} / \mathrm{g}$, respectively.
\end{abstract}

Keywords: Cheese, Ice cream, PCR, Virulence genes, Y. enterocolitica.
Original Article:

DOI:https://dx.doi.org/10.21608/javs.20 $\underline{21.154573}$

Received :05 January, 2021.

Accepted:22 February, 2021.

Published in April, 2021.

This is an open access article under the term of the Creative Commons Attribution 4.0 (CCBY) International License. To view a copy of this license, visit:

http://creativecommons.org/licenses/by/4.0/

J. Appl. Vet. Sci., 6(2): 1 - 14 .

\section{INTRODUCTION}

Microbial safety is considered the focal theme in the current food industry scenario, so more advanced methods for detecting microorganisms and their pathogenicity have been evolved over the years (Severgnini, et al., 2011). Recently, food-borne outbreaks are associated with the consumption of milk and milk products, which have been contaminated with pathogenic bacteria like Listeria, salmonella, campylobacter and Yersinia spp. (Gram et al., 2002).
Yersinia enterocolitica is a well-known foodborne infectious agent that cause enteric disease in human with abundant gastrointestinal disorders ranging from mild diarrhea, inflammation of the mesenteric glands, appendicitis, septicemia in children to underlying disease. Yersiniosis is recorded in the third place among food-borne illness after campylobacteriosis and salmonellosis (Bottone, 1997; Bolton et al., 2013).

The Genus Yersinia is a member of the Enterobacteriaceae family and comprises 17 gramnegative bacteria, many of which are non-pathogenic, 
but $Y$. enterocolitica, $Y$. pestis and $Y$. pseudotuberculosis are considered pathogenic for human. Y. enterocolitica includes a very heterogeneous group of strains which are classified biochemically to 6 biovars $(1 \mathrm{~A}, 1 \mathrm{~B}, 2,3,4$ and 5). The strains of biovars1B, 2, 3, 4 and 5 are considered pathogenic due to their possession of the virulence plasmid (pYV) and the chromosomal genes ail, ystA, myfA and hreP however the strains that belong to biotype 1A are nonpathogenic because they have not pYV plasmid and the chromosomally encoded genes (Bahgat and Virdi, 2007; Shurnik and Toivonen, 2011; Anna and Jordi, 2012). Serologically, more than 70 serotypes were detected and the most frequent serotypes that cause human infection are O: 3, O: 5, 27, O: 8 and O: 9 (Vazlerova and steinhauserova, 2006).

Yersinia enterocolitica can contaminate milk, meat, eggs, seafood and vegetables primary or secondary during food processing. This pathogen is ubiquitously found in the environment which gets contaminated with feces of infected humans and animals. Humans get the infection through ingested contaminated food (Nusrat et al., 2009; FredrikssonAhomaa, et al., 2010).

Yersinia enterocolitica has become of particular public health concern because of its nature as a psychrotrophic bacterium, where the pathogenic strains of $Y$. enterocolitica have the ability to survive and multiply at a temperature as low as $-5^{\circ} \mathrm{C}$ without inducing apparent signs of food spoilage. Its ability to grow at low temperatures is owing to the nature and structure of the plasma membrane which can undergo a phase of transition from a liquid crystalline state to a rigid gel when exposed to low temperature. In addition to the relatively resistance of its enzymatic systems to freezing and remain active even at $-30^{\circ} \mathrm{C}$ (Iliev and Najdenski, 2008 and Rakesh, 2007).

There is no need to prove that cheese and ice cream are the most common milk products stored by refrigeration and freezing process which are consumed by a wide range of people all over the world and these milk products may be contaminated with $Y$. enterocolitica from milk used in manufacturing or during processing and storage.

Because of the wide consuming cheese and ice cream and the psychotropic nature of $Y$. enterocolitica, this investigation aimed to detect the prevalence of $Y$. enterocolitica in these products and confirm the pathogenic strains' behavioral patterns during refrigeration and freezing as different storage aspects of cheese and ice cream.

\section{MATERIALS AND METHODS}

\section{Samples}

A total of 80 random samples were collected from supermarkets in Assiut city, Egypt including 40 samples for Damietta cheese and 40 samples for nonindustrial ice cream. The samples were delivered to the laboratory immediately in an icebox.

\section{Isolation of Y. enterocolitica}

Twenty-five grams of the sample was aseptically added to phosphate-buffered saline (PBS) in a stomacher bag and homogenized for $2 \mathrm{~min}$; then, the homogenate was incubated $2 \mathrm{~min}$ at $25^{\circ} \mathrm{C}$. Twenty $\mathrm{ml}$ of the homogenate was added to $80 \mathrm{ml}$ trypticase soya broth (TSB) and incubated at $25^{\circ} \mathrm{C}$ for $24 \mathrm{~h}$, and then, the enrichment broth was treated with $\mathrm{KOH}$ $(0.5 \% \mathrm{KOH}$ in $0.5 \%$ saline) to inhibit other flora in the broth.

Loopfull from the inoculated broth was streaked on cefsulodin irgasan novobiocin agar (CIN) with Yersinia selective supplement (Merck Germany) and incubated at $25^{\circ} \mathrm{C}$ for $48 \mathrm{~h}$ for the appearance of the suspected typical "bull's eye" colonies. After that, the colonies were streaked on tryptone soya agar plates for purification. The purified colonies were examined for gram staining, utilization of Simmons citrate, kliglers iron agar reaction and urease activity (MacFaddin 2000; FDA, 2007).

\section{Confirmation of the isolated strains by using PCR}

Yersinia enterocolitica strains that were previously isolated and identified were confirmed using the PCR technique in the Reference Laboratory for Veterinary Quality Control on Poultry Production in Animal Health Research Institute, Dokki, Giza, Egypt according to Wannet et al., (2001).

\section{DNA extraction}

DNA extraction from samples was performed using the QIAamp DNA Mini kit (Qiagen, Germany, $\mathrm{GmbH}$ ) with modifications from the manufacturer's recommendations. Briefly, $200 \mu \mathrm{l}$ of the sample suspension was incubated with $10 \mu \mathrm{l}$ of proteinase $\mathrm{K}$ and $200 \mu \mathrm{l}$ of lysis buffer at $56^{\circ} \mathrm{C}$ for $10 \mathrm{~min}$. After incubation, $200 \mu \mathrm{l}$ of $100 \%$ ethanol was added to the lysate. The sample was then washed and centrifuged following the manufacturer's recommendations. Nucleic acid was eluted with $100 \mu$ l of elution buffer provided in the kit. 


\section{Oligonucleotide Primer}

Primers used were supplied from Metabion (Germany) are listed in Table (1). PCR, Primers were utilized in a $25-\mu 1$ reaction containing $12.5 \mu \mathrm{l}$ of Emerald Amp Max PCR Master Mix (Takara, Japan), 1 $\mu 1$ of each primer of 20 pmol concentration, $4.5 \mu \mathrm{l}$ of water, and $6 \mu 1$ of DNA template. The reaction was performed in an applied biosystem 2720 thermal cycler.

\section{Analysis of the PCR Products}

The PCR products were separated by electrophoresis on $1 \%$ agarose gel (Applichem, Germany, GmbH) in $1 \mathrm{x}$ TBE buffer at room temperature using gradients of $5 \mathrm{~V} / \mathrm{cm}$. For gel analysis, $20 \mu$ l of the uniplex PCR products were loaded in each gel slot. Generuler 100 bp DNA Ladder (Fermentas, Thermo, Germany) was used to determine the fragment sizes. The gel was photographed by a gel documentation system (Alpha Innotech, Biometra), and the data were analyzed through computer software.

\section{Bio- typing of $Y$. enterocolitica strains}

The confirmed $Y$. enterocolitica strains by PCR were bio- typed biochemically by Esculin hydrolysis, Indole production, Voges Proskuaer, Nitrate reduction, Xylose fermentation, Trehalose fermentation, Salicin fermentation and $\beta$ - Glucosidase tests according to Schriefer and Petersen (2011).

\section{Serotyping of the isolates}

The commercial antisera (O: 3, O: 4, O: 5, O: 8 , O: 9 \& O: 14) were applied for the demonstration of various serotypes of $Y$. enterocolitica. Briefly, the suspected culture was suspended in normal saline and one drop of the definite antiserum was individually added to one drop of the suspension. The positive result was attained by agglutination according to Tennat et al., (2003).

\section{Detection of the virulence genes}

The previously bio- typed pathogenic strains of $Y$. enterocolitica were sent to the Reference Laboratory for Veterinary Quality Control on Poultry Production in Animal Health Research Institute, Dokki, Giza, Egypt for detection of the chromosomal virulence ail and yst genes according to Wannet $\boldsymbol{e t}$ al., (2001); Koua et al., ( 2014).

7. Behavioral patterns of $Y$. enterocolitica in Damietta cheese and ice cream:

\section{Culture Preparation:}

Strains of $Y$. enterocolitica O: 3 biotypes 2 used in the experiment were the previously isolated strains from cheese and ice cream. They were propagated in tryptone soya broth at $25^{\circ} \mathrm{C}$ for $48 \mathrm{~h}$ and tenfold serial dilution was carried out and matched to McFarland tubes to determine the density of the organism in the broth.

7.1. Effect of refrigeration temperature $\left(4 \pm 2^{\circ} \mathrm{C}\right)$ on the survival of $Y$. enterocolitica in Damietta cheese

\section{Preparation of Cheese}

Four liters of pasteurized condensed milk were obtained from Animal Production Research Institute and examined for $Y$. enterocolitica before used to make sure it was free from the organism; then, sodium chloride was added in a concentration of $3 \%$ and warmed to $40^{\circ} \mathrm{C}$. Thereafter, rennet was added according to the manufacturer, and two portions were taken before inoculation as two control negative samples. The rest was inoculated with $Y$. enterocolitica serotype O: 3 isolated from the examined cheese to yield $5 \times 10^{6} \mathrm{cfu} / \mathrm{g}$ and divided into six portions that were poured in the containers and were left at room temperature till curdling. Samples from each portion were taken to detect the initial count before keeping three portions at $30 \pm 2{ }^{\circ} \mathrm{C}$ and the second three portions and control negative samples were kept at refrigeration temperature $\left(4 \pm 2^{\circ} \mathrm{C}\right)$ for 18 weeks. The prepared cheese portions were examined to determine the count of $Y$. enterocolitica on the $1^{\text {st }}, 5^{\text {th }}$ days and every week in the first month. Then, the count was determined every two weeks till the $14^{\text {th }}$ week and finally in the $18^{\text {th }}$ weeks of storage.

\subsection{Effect of freezing at $-6 \pm 2^{\circ} \mathrm{C}$ and $-18 \pm 2^{\circ} \mathrm{C}$ on the survival of $Y$. enterocolitica in ice cream Preparation of ice cream}

The ice cream was prepared from ice cream powder packets in the laboratory according to the manufacturer and two control portions were taken before inoculation. The rest was inoculated with $Y$. enterocolitica serotype $\mathrm{O}: 3$ isolated from the examined ice cream to yield a count of $5 \times 10^{6} \mathrm{cfu} / \mathrm{g}$ and divided into six portions; three portions were stored at $6 \pm 2^{\circ} \mathrm{C}$ and the other three portions at $-18 \pm 2^{\circ} \mathrm{C}$. Samples from two controls and six portions were examined to determine the initial count of the organism before freezing storage, and the count after freezing was detected on $1^{\text {st }}, 3^{\text {rd }}, 5^{\text {th }}$ days and in the $1^{\text {st }}$ and $2^{\text {nd }}$ weeks, then, the microbial load was determined every two weeks till the end of the experiment.

\section{Statistical analysis}

The statistical analysis was performed using IBM SPSS (IBM CO. Version), and data statistics analysis was transforming after $\log _{10}$ values. The mean value of compared using T-test at $\alpha<0.05$. 
Table 1: Primers sequences, target genes, amplicon sizes and cycling conditions.

\begin{tabular}{|c|c|c|c|c|c|c|c|}
\hline \multirow[b]{2}{*}{ Target gene } & \multirow[b]{2}{*}{ Primers sequences } & \multirow[b]{2}{*}{ 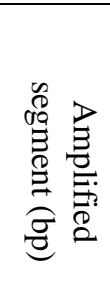 } & \multirow[b]{2}{*}{ 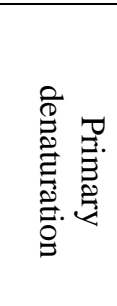 } & \multicolumn{3}{|c|}{ Amplification (35 cycles) } & \multirow[b]{2}{*}{ 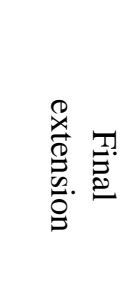 } \\
\hline & & & & 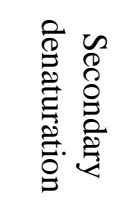 & 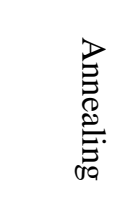 & $\begin{array}{l}\frac{1}{x} \\
\stackrel{0}{0} \\
0 \\
0 \\
0 \\
0\end{array}$ & \\
\hline \multirow[t]{2}{*}{$\begin{array}{c}Y . \text { enterocolitica } \\
16 S \text { rRNA }\end{array}$} & AAT ACC GCA TAA CGT CTT CG & \multirow[t]{2}{*}{330} & \multirow[t]{2}{*}{$\begin{array}{l}94^{\circ} \mathrm{C} \\
5 \mathrm{~min} .\end{array}$} & \multirow[t]{2}{*}{$\begin{array}{c}94^{\circ} \mathrm{C} \\
30 \mathrm{sec} .\end{array}$} & \multirow[t]{2}{*}{$\begin{array}{l}62^{\circ} \mathrm{C} \\
40 \mathrm{sec} .\end{array}$} & \multirow{2}{*}{$\begin{array}{c}72^{\circ} \mathrm{C} \\
40 \\
\text { sec. }\end{array}$} & \multirow[t]{2}{*}{$\begin{array}{c}72^{\circ} \mathrm{C} \\
10 \mathrm{~min} .\end{array}$} \\
\hline & CTT CTT CTG CGA GTA ACG TC & & & & & & \\
\hline \multirow[t]{2}{*}{ Ail } & TAATGTGTACGCTGCGAG & \multirow[t]{2}{*}{351} & \multirow{2}{*}{$\begin{array}{l}94^{\circ} \mathrm{C} \\
5 \mathrm{~min} .\end{array}$} & \multirow{2}{*}{$\begin{array}{c}94^{\circ} \mathrm{C} \\
30 \mathrm{sec} .\end{array}$} & \multirow{2}{*}{$\begin{array}{l}55^{\circ} \mathrm{C} \\
40 \mathrm{sec} .\end{array}$} & $72^{\circ} \mathrm{C}$ & \multirow{2}{*}{$\begin{array}{c}72^{\circ} \mathrm{C} \\
10 \mathrm{~min} .\end{array}$} \\
\hline & GACGTCTTACTTGCACTG & & & & & sec. & \\
\hline \multirow[t]{2}{*}{$Y s t$} & AATGCTGTCTTCATTTGGAGC & \multirow[t]{2}{*}{145} & \multirow{2}{*}{$\begin{array}{l}94^{\circ} \mathrm{C} \\
5 \mathrm{~min} .\end{array}$} & \multirow{2}{*}{$\begin{array}{c}94^{\circ} \mathrm{C} \\
30 \mathrm{sec} .\end{array}$} & \multirow{2}{*}{$\begin{array}{l}55^{\circ} \mathrm{C} \\
30 \mathrm{sec} .\end{array}$} & $72^{\circ} \mathrm{C}$ & \multirow{2}{*}{$\begin{array}{l}72^{\circ} \mathrm{C} \\
7 \mathrm{~min} .\end{array}$} \\
\hline & ATCCCAATCACTACTGACTTC & & & & & $\begin{array}{c}30 \\
\text { sec. }\end{array}$ & \\
\hline
\end{tabular}

\section{RESULTS}

Yersinia enterocolitica could be isolated from 17.5 and $2.5 \%$ of the examined cheese and ice cream samples. At the same time, $Y$. frenderikenii could be detected in $2.5 \%$ of the examined cheese and ice cream samples, respectively. On the other hand, $Y$. intermedia was found on $2.5 \%$ of the tested ice cream samples and was not isolated from cheese samples (table, 2).

Table 2: Prevalence of Yersinia species in the examined samples based on culture method

\begin{tabular}{|l|c|c|c|c|}
\hline \multirow{2}{*}{ Yersinia spp. } & \multicolumn{2}{|c|}{ Damietta cheese } & \multicolumn{2}{c|}{ Ice Cream } \\
\cline { 2 - 5 } & No. & $\%$ & No. & $\%$ \\
\hline$Y$. enterocolitica & $7 / 40$ & 17.5 & $10 / 40$ & 25.0 \\
\hline$Y$. Frenderikenii & $1 / 40$ & 2.5 & $1 / 40$ & 2.5 \\
\hline$Y$. intermedia & - & - & $1 / 40$ & 2.5 \\
\hline Total & $8 / 40$ & 20.0 & $12 / 40$ & 30.0 \\
\hline
\end{tabular}

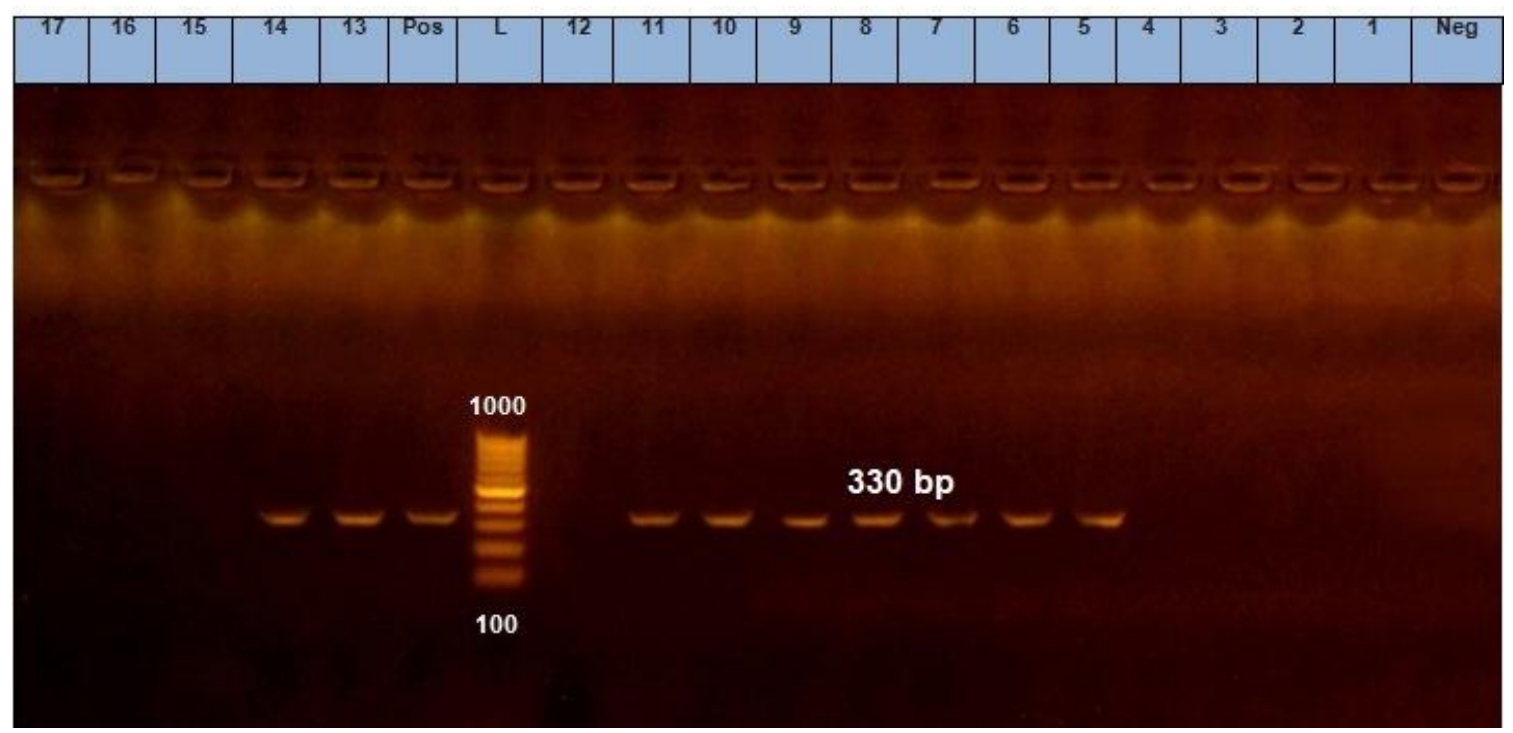

Fig. 1: Confirmation of the isolated $Y$. enterocolitica strains 


\section{Salwa S.Thabet and Manal H.Thabet}

Molecular confirmation of the isolated strains from cheese and ice cream revealed that 3 and 6 out of the identified strains were confirmed positive for $Y$. enterocolitica with a 42.8 and $60 \%$ percentage, respectively. Consequently, the incidence of $Y$. enterocolitica in the tested cheese and ice cream samples was 7.5 and $15.0 \%$, respectively (table, 3 ).

Table 3: Results of molecular conformation of the isolated $Y$. enterocolitica strains by using PCR technique

\begin{tabular}{|l|c|c|c|c|}
\hline \multirow{2}{*}{ Samples } & \multicolumn{2}{|c|}{$\begin{array}{c}\text { Prevalence of } Y \text {. enterocolitica in the } \\
\text { isolated strains }\end{array}$} & $\begin{array}{c}\text { Incidence of } Y \text {. enterocolitia in the } \\
\text { examined samples }\end{array}$ \\
\cline { 2 - 5 } & No. & $\%$ & No. & $\%$ \\
\hline Damietta cheese & $3 / 7$ & 42.8 & $3 / 40$ & 7.5 \\
\hline Ice cream & $6 / 10$ & 60.0 & $6 / 40$ & 15.0 \\
\hline
\end{tabular}

The results of bio- typing and serotyping revealed that, 8 out of the confirmed strains have belonged to bio- type 2, 4 and 5 and one strain was bio- typed 1A. On the other hand, $66.66 \%$ and $50 \%$ of the isolated strains from cheese and ice cream were belonged to O: 3. In addition, serotype O: 8 was found in a frequency of $33.3 \%$ in cheese, while, serotypes O: 8, O: 4 and O: 5 were found in a percentage of $16.66 \%$ of the isolated strains from ice cream (table, 4$)$.

Table 4: Bio- typing and serotyping of the confirmed $Y$. enterocolotica strains.

\begin{tabular}{|l|c|c|c|c|}
\hline \multirow{2}{*}{ Strain } & \multicolumn{2}{|c|}{ Damietta cheese } & \multicolumn{2}{c|}{ Ice cream } \\
\cline { 2 - 5 } & No. & $\%$ & No. & $\%$ \\
\hline O:3/ biotype 2 & 1 & 33.3 & 1 & 33.33 \\
\hline O:3/ biotype 4 & 1 & 33.3 & - & 16.66 \\
\hline O:8/ biotype 2 & 1 & 33.3 & 1 & 16.66 \\
\hline O:8/ biotype 4 & - & - & 1 & 16.66 \\
\hline O:4/ biotype 1A & - & - & 6 & 16.66 \\
\hline O:5/ biotype 5 & - & - & 100 \\
\hline Total & 3 & 100 & & 100 \\
\hline
\end{tabular}

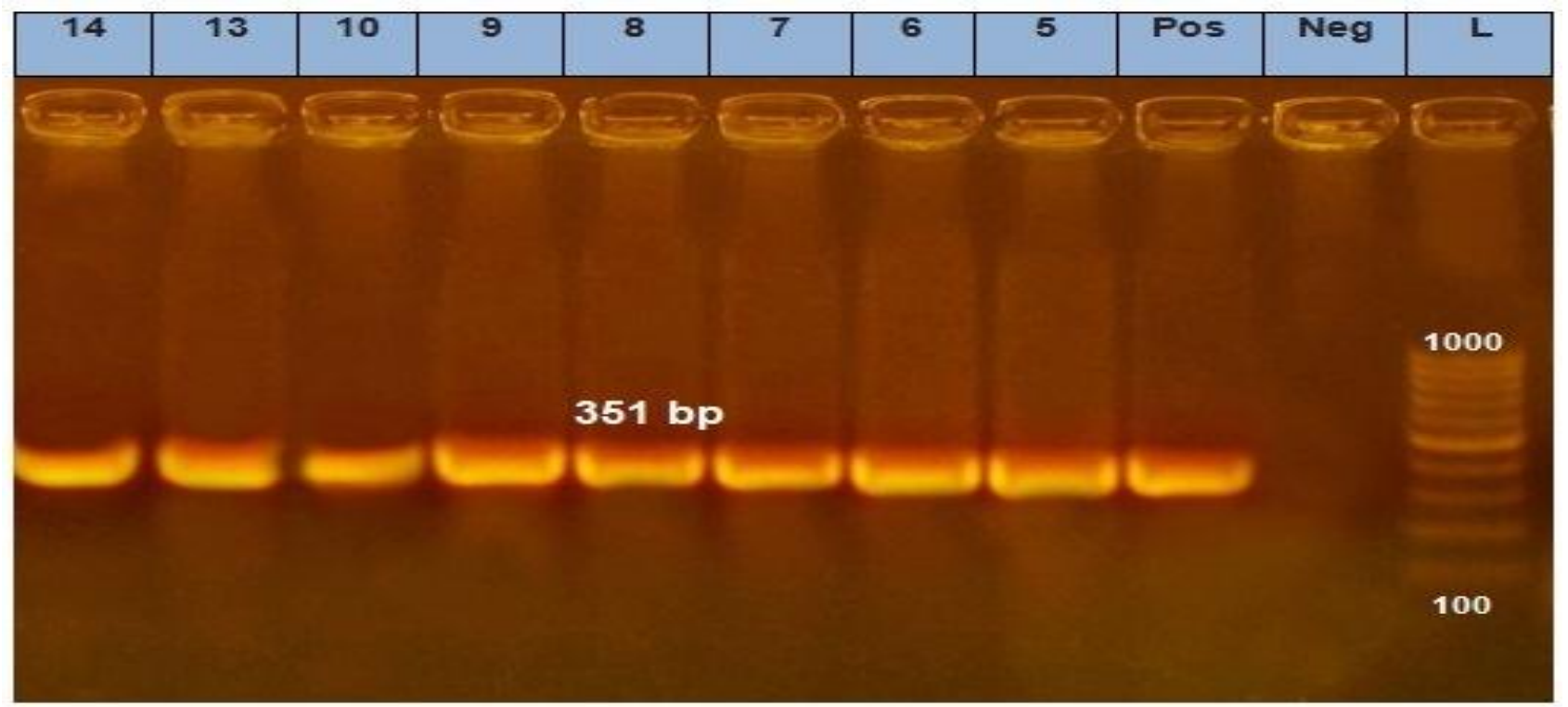

Fig. 2: Detection of the virulent ail gene. 


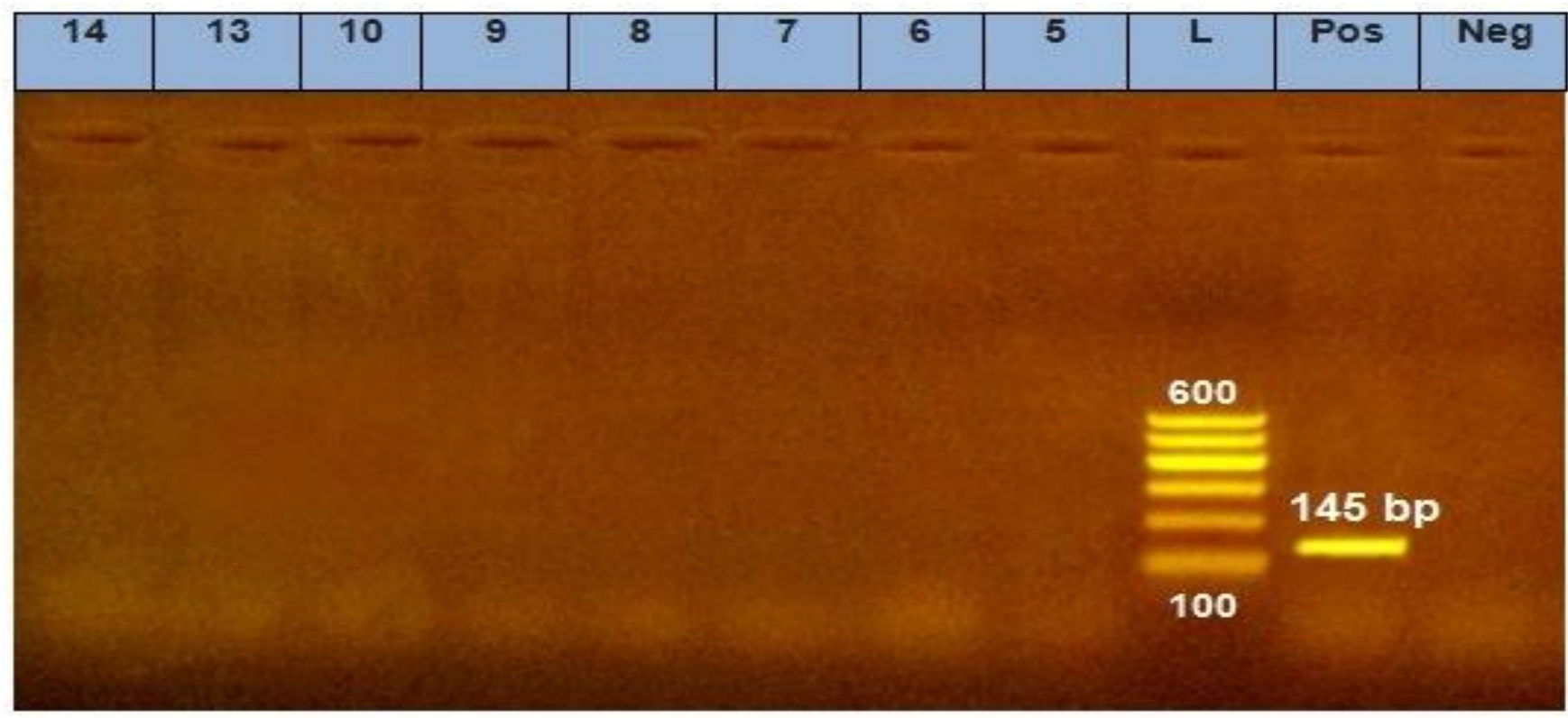

Fig.3: Detection of the virulent yst gene

The results of PCR detection of the virulent genes revealed that all the confirmed pathogenic $Y$. enterocolitica strains carried the ail gene, while, yst gene was failed to be detected, as observed in figures (2\&3).

The initial count of the organism was $5.9,6.5$, and 5.0 with a mean value of $5.8 \pm 0.75 \operatorname{logs} \mathrm{cfu} / \mathrm{g}$ and at the $1^{\text {st }}$ day, its count was $6.2,7.0$ and $6.5 \mathrm{log} \mathrm{cfu} / \mathrm{g}$ and the mean value was $6.6 \pm 0.40 \mathrm{log} \mathrm{cfu} / \mathrm{g}$. and returned to decrease on the $5^{\text {th }}$ day to $4.9 \pm 0.92 \operatorname{logs} \mathrm{cfu} / \mathrm{g}$. A gradual increase in the microbial load from the $1^{\text {st }}$ to the $10^{\text {th }}$ week was recorded, where the mean value was increased from $5.1 \pm 0.34$ to $10.2 \pm 0.74 \mathrm{log} \mathrm{cfu} / \mathrm{g}$. The mean value of the count in the $14^{\text {th }}$ week was $9.4 \pm 0.35$ and the count was $8.0,6.2$ and $7.0 \mathrm{log} \mathrm{cfu} / \mathrm{g}$ at the end of the experiment and the mean value was $7.4 \pm 0.50 \mathrm{log} \mathrm{cfu} / \mathrm{g}$ (table, 5).

Table 5: Survival of $Y$. enterocolitica in cheese during refrigeration storage

\begin{tabular}{|l|c|c|c|c|}
\hline Storage time & $\begin{array}{c}\text { Trial 1 } \\
(\log c f u / g)\end{array}$ & $\begin{array}{c}\text { Trail 2 } \\
(\log \text { cfu/g) }\end{array}$ & $\begin{array}{c}\text { Trail 3 } \\
(\log \text { cfu/g) }\end{array}$ & $\begin{array}{c}\text { Mean } \\
(\log \text { cfu/g) }\end{array}$ \\
\hline Time zero & 5.9 & 6.5 & 5.0 & $5.8 \pm 0.75$ \\
\hline $1^{\text {st }}$ day & 6.9 & 7.0 & 6.5 & $6 . .6 \pm 0.40$ \\
\hline $5^{\text {th }}$ day & 5.0 & 4.1 & 5.9 & $4.9 \pm 0.92$ \\
\hline $1^{\text {st }}$ week & 5.1 & 4.8 & 5.5 & $5.1 \pm 0.34$ \\
\hline $2^{\text {nd }}$ week & 7.1 & 6.9 & 8.1 & $7.4 \pm 0.63$ \\
\hline $3^{\text {rd }}$ week & 6.9 & 6.5 & 7.0 & $6.8 \pm 0.25$ \\
\hline $4^{\text {th }}$ week & 7.5 & 8.0 & 8.0 & $7.8 \pm 0.27$ \\
\hline $6^{\text {th }}$ week & 7.6 & 7.9 & 8.1 & $7.8 \pm 0.16$ \\
\hline $8^{\text {th }}$ week & 10.0 & 9.7 & 10.0 & $9.9 \pm 0.16$ \\
\hline $10^{\text {th }}$ week & 10.5 & 9.4 & 10.3 & $10.1 \pm 0.74$ \\
\hline $14^{\text {th }}$ week & 9.7 & 9.0 & 9.5 & $9.4 \pm 0.35$ \\
\hline $18^{\text {th }}$ week & 8.0 & 7.2 & 7.0 & $7.4 \pm 0.50$ \\
\hline
\end{tabular}


There was a low decreasing percentage in the count of $Y$. enterocolitica on the first day and the microbial load was 5.6, 6.3 and $5.4 \mathrm{log} \mathrm{cfu} / \mathrm{g}$ with a mean value of $5.8 \pm 0.48 \mathrm{log} \mathrm{cfu} / \mathrm{g}$. Then the count was increased on the $5^{\text {th }}$ day. The mean value for the bacterial cells count was $6.3 \pm 0.46 \log \mathrm{cfu} / \mathrm{g}$, and a continuous increase in the count was reported till the number of the organism reach its highest value in the $10^{\text {th }}$ week and the count was 11.0, 10.9 and $10.5 \log \mathrm{cfu} / \mathrm{g}$ with a mean value of $10.8 \pm 0.27 \mathrm{log} \mathrm{cfu} / \mathrm{g}$. The count was rapidly decreased in the $14^{\text {th }}$ and $18^{\text {th }}$ weeks with a mean value of $9.2 \pm 0.65$ and $6.9 \pm 0.16 \mathrm{log}$ cfu/g, respectively (table, 6).

Table 6: Survival of $Y$. enterocolitica in cheese during storage at room temperature

\begin{tabular}{|l|c|c|c|c|}
\hline Storage time & $\begin{array}{c}\text { Trial 1 } \\
(\log \mathrm{cfu} / \mathrm{g})\end{array}$ & $\begin{array}{c}\text { Trail } 2 \\
(\log \mathrm{cfu} / \mathrm{g})\end{array}$ & $\begin{array}{c}\text { Trail 3 } \\
(\log \mathrm{cfu} / \mathrm{g})\end{array}$ & $\begin{array}{c}\text { Mean } \\
(\log \mathrm{cfu} / \mathrm{g})\end{array}$ \\
\hline Time zero & 5.9 & 6.6 & 5.6 & $6.1 \pm 0.50$ \\
\hline $1^{\text {st }}$ day & 5.6 & 6.3 & 5.4 & $5.8 \pm 0.48$ \\
\hline $5^{\text {th }}$ day & 6.5 & 6.6 & 5.8 & $6.3 \pm 0.46$ \\
\hline $1^{\text {st }}$ week & 7.0 & 7.0 & 5.5 & $6.5 \pm 0.85$ \\
\hline $2^{\text {nd }}$ week & 7.6 & 8.0 & 8.9 & $8.2 \pm 0.68$ \\
\hline $3^{\text {rd }}$ week & 8.0 & 7.9 & 8.2 & $8.0 \pm 0.15$ \\
\hline $4^{\text {th }}$ week & 8.8 & 8.1 & 9.0 & $8.6 \pm 0.45$ \\
\hline $6^{\text {th }}$ week & 8.0 & 8.5 & 9.0 & $8.5 \pm 0.47$ \\
\hline $8^{\text {th }}$ week & 9.1 & 9.8 & 9.80 & $9.6 \pm 0.41$ \\
\hline $10^{\text {th }}$ week & 11.0 & 10.9 & 10.5 & $10.8 \pm 0.27$ \\
\hline $14^{\text {th }}$ week & 8.6 & 9.9 & 9.0 & $9.2 \pm 0.65$ \\
\hline $18^{\text {th }}$ week & 7.0 & 7.0 & 6.7 & $6.9 \pm 0.16$ \\
\hline
\end{tabular}

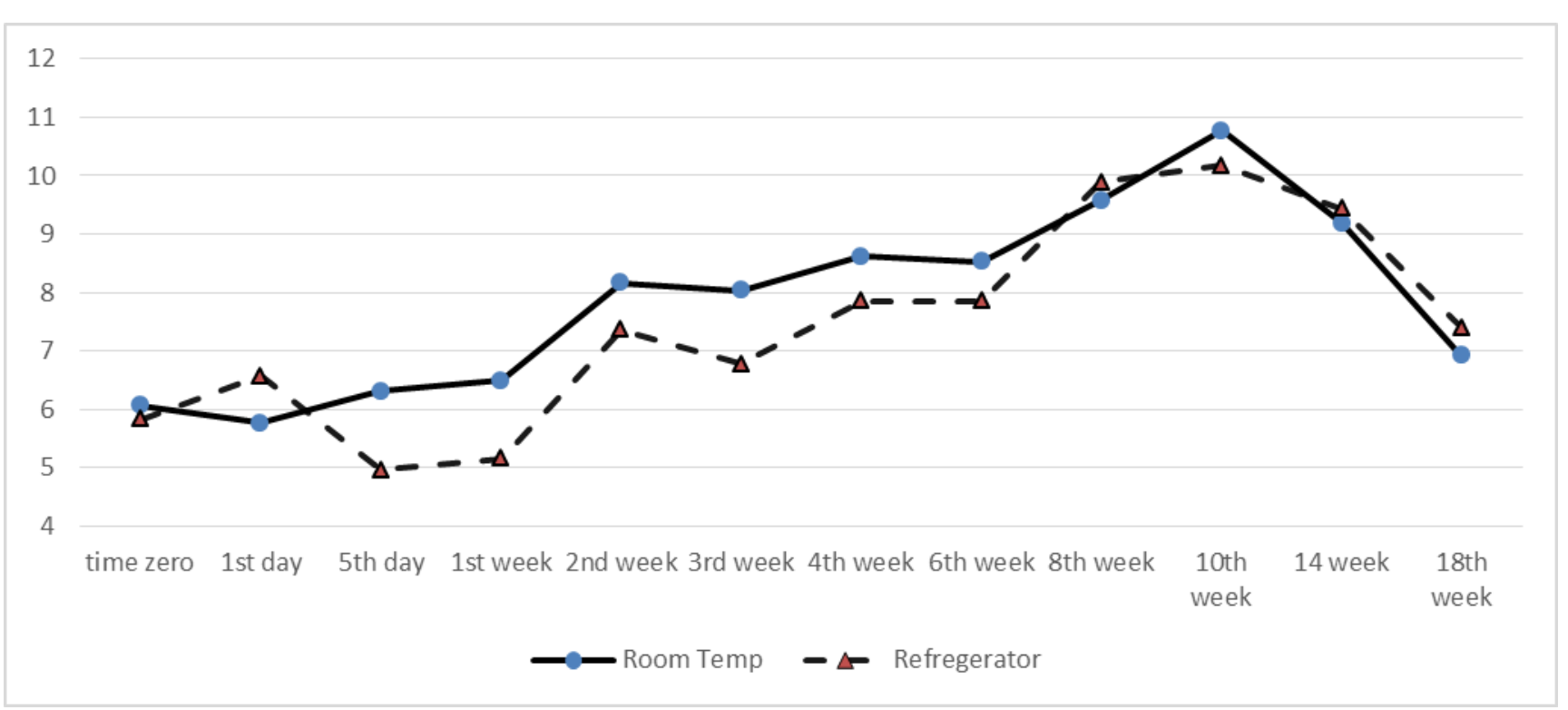

Fig.4: Survival of $Y$. enterocolitica in cheese

There are significant differences $(\mathrm{P}<0.05)$ between means in the $3^{\text {rd }}$ week.

During freezing of ice cream at $-6 \pm 2{ }^{\circ} \mathrm{C}$ there was a slight increase in the count of the organism and the count was 6.6, 6.2 and $7.0 \mathrm{log} \mathrm{cfu} / \mathrm{g}$ with a mean value of $6.6 \pm 0.40 \mathrm{log} \mathrm{cfu} / \mathrm{g}$ on the first day and return to decrease on the $3^{\text {rd }}$ and 5th days with a mean value of $6.2 \pm 0.68$ and $6.3 \pm 0.14 \log \mathrm{cfu} / \mathrm{g}$, then, the count was increased to $6.9 \pm 0.16 \mathrm{log} \mathrm{cfu} / \mathrm{g}$ in the $1^{\text {st }}$ week. In the $2^{\text {nd }}$ week, the bacterial population declined to $6.5 \pm 0.45$ $\log \mathrm{cfu} / \mathrm{g}$. The highest increasing percentage was noted in the $4^{\text {th }}$ week with a mean value of $8.2 \pm 0.46 \log \mathrm{cfu} / \mathrm{g}$ 
and from this time to the end of the experiment, there was a decrease in the count, where the mean value of the organism was declined to $5.5,5.2$ and $5.0 \mathrm{log} \mathrm{cfu} / \mathrm{g}$ in the $16^{\text {th }}$ week with a mean value of $5.3 \pm 0.26 \log \mathrm{cfu} / \mathrm{g}$ (table, 7).

Table 7: Behavioral patterns of $Y$. enterocolitica in ice cream during freezing storage at $-6 \pm 2{ }^{\circ} \mathrm{C}$ :

\begin{tabular}{|c|c|c|c|c|}
\hline Storage time & $\begin{array}{c}\text { Trial } 1 \\
(\log \mathrm{cfu} / \mathrm{g})\end{array}$ & $\begin{array}{c}\text { Trail } 2 \\
(\log \mathrm{cfu} / \mathrm{g})\end{array}$ & $\begin{array}{c}\text { Trail } 3 \\
(\log \mathrm{cfu} / \mathrm{g})\end{array}$ & $\begin{array}{c}\text { Mean } \\
(\log c f u / g)\end{array}$ \\
\hline Time zero & 6.5 & 6.0 & 6.4 & $6.3 \pm 0.26$ \\
\hline $1^{\text {st }}$ day & 6.6 & 6.2 & 7.0 & $6.6 \pm 0.40$ \\
\hline $3^{\text {rd }}$ day & 5.6 & 7.0 & 6.1 & $6.2 \pm 0.68$ \\
\hline $5^{\text {th }}$ day & 6.4 & 6.4 & 6.2 & $6.3 \pm 0.14$ \\
\hline $1^{\text {st }}$ week & 6.7 & 7.0 & 7.0 & $6.9 \pm 0.16$ \\
\hline $2^{\text {nd }}$ week & 6.0 & 6.5 & 6.9 & $6.5 \pm 0.45$ \\
\hline $4^{\text {th }}$ week & 8.7 & 8.1 & 7.8 & $8.2 \pm 0.46$ \\
\hline $6^{6^{\text {th }}}$ week & 7.9 & 7.7 & 8.5 & $8.0 \pm 0.37$ \\
\hline $8^{\text {th }}$ week & 6.0 & 6.8 & 5.8 & $6.2 \pm 0.49$ \\
\hline $12^{\text {th }}$ week & 6.0 & 5.0 & 4.9 & $5.3 \pm 0.58$ \\
\hline $16^{\text {th }}$ week & 5.5 & 5.2 & 5.0 & $5.3 \pm 0.26$ \\
\hline
\end{tabular}

There was a reduction in the mean value of the bacterial population from $6.7 \pm 0.43 \mathrm{log} \mathrm{cfu} / \mathrm{g}$ to $6.3 \pm$ 0.52 and $5.3 \pm 0.62 \log \mathrm{cfu} / \mathrm{g}$ on the $1^{\mathrm{st}}$ and $3^{\text {rd }}$ days of ice cream storage at $-18 \pm 2^{\circ} \mathrm{C}$. On the contrary, there was a high, increasing percentage from the $3^{\text {rd }}$ day to the $2^{\text {nd }}$ week, where the recorded mean value was $8.4 \pm 0.46 \log$ $\mathrm{cfu} / \mathrm{g}$ in the $2^{\text {nd }}$ week. Reduction in the count of $Y$. enterocolitica started from the $4^{\text {th }}$ week to the end of this treatment with a mean value of $5.6 \pm 0.39 \mathrm{log} \mathrm{cfu} / \mathrm{g}(\mathrm{table}, 8)$.

Table 8: Behavioral patterns of $Y$. enterocolitica during storage of ice cream at $-18 \pm 2{ }^{\circ} \mathrm{C}$ :

\begin{tabular}{||l|c|c|c|c||}
\hline Storage time & $\begin{array}{c}\text { Trial } 1 \\
(\log \mathrm{cfu} / \mathrm{g})\end{array}$ & $\begin{array}{c}\text { Trail } 2 \\
(\log \mathrm{cfu} / \mathrm{g})\end{array}$ & $\begin{array}{c}\text { Trail 3 } \\
(\log \mathrm{cfu} / \mathrm{g})\end{array}$ & $\begin{array}{c}\text { Mean } \\
(\log \mathrm{cfu} / \mathrm{g})\end{array}$ \\
\hline Time zero & 6.4 & 6.8 & 5.9 & $6.7 \pm 0.43$ \\
\hline $1^{\text {st }}$ day & 6.6 & 6.7 & 5.7 & $6.3 \pm 0.52$ \\
\hline $3^{\text {rd }}$ day & 4.9 & 6.0 & 5.0 & $5.3 \pm 0.62$ \\
\hline $5^{\text {th }}$ day & 6.6 & 7.0 & 7.5 & $7.0 \pm 0.48$ \\
\hline $1^{\text {st }}$ week & 7.0 & 7.0 & 7.7 & $7.9 \pm 0.48$ \\
\hline $2^{\text {nd }}$ week & 8.9 & 8.2 & 8.1 & $8.4 \pm 0.46$ \\
\hline $4^{\text {th }}$ week & 7.7 & 7.4 & 8.0 & $7.7 \pm 0.30$ \\
\hline $6^{\text {th }}$ week & 7.6 & 6.3 & 6.4 & $6.8 \pm 0.72$ \\
\hline $8^{\text {th }}$ week & 6.0 & 5.9 & 5.6 & $5.8 \pm 0.19$ \\
\hline $12^{\text {th }}$ week & 5.8 & 5.9 & 4.8 & $5.5 \pm 0.62$ \\
\hline $16^{\text {th }}$ week & 5.8 & 5.9 & 5.1 & $5.6 \pm 0.39$ \\
\hline \hline
\end{tabular}




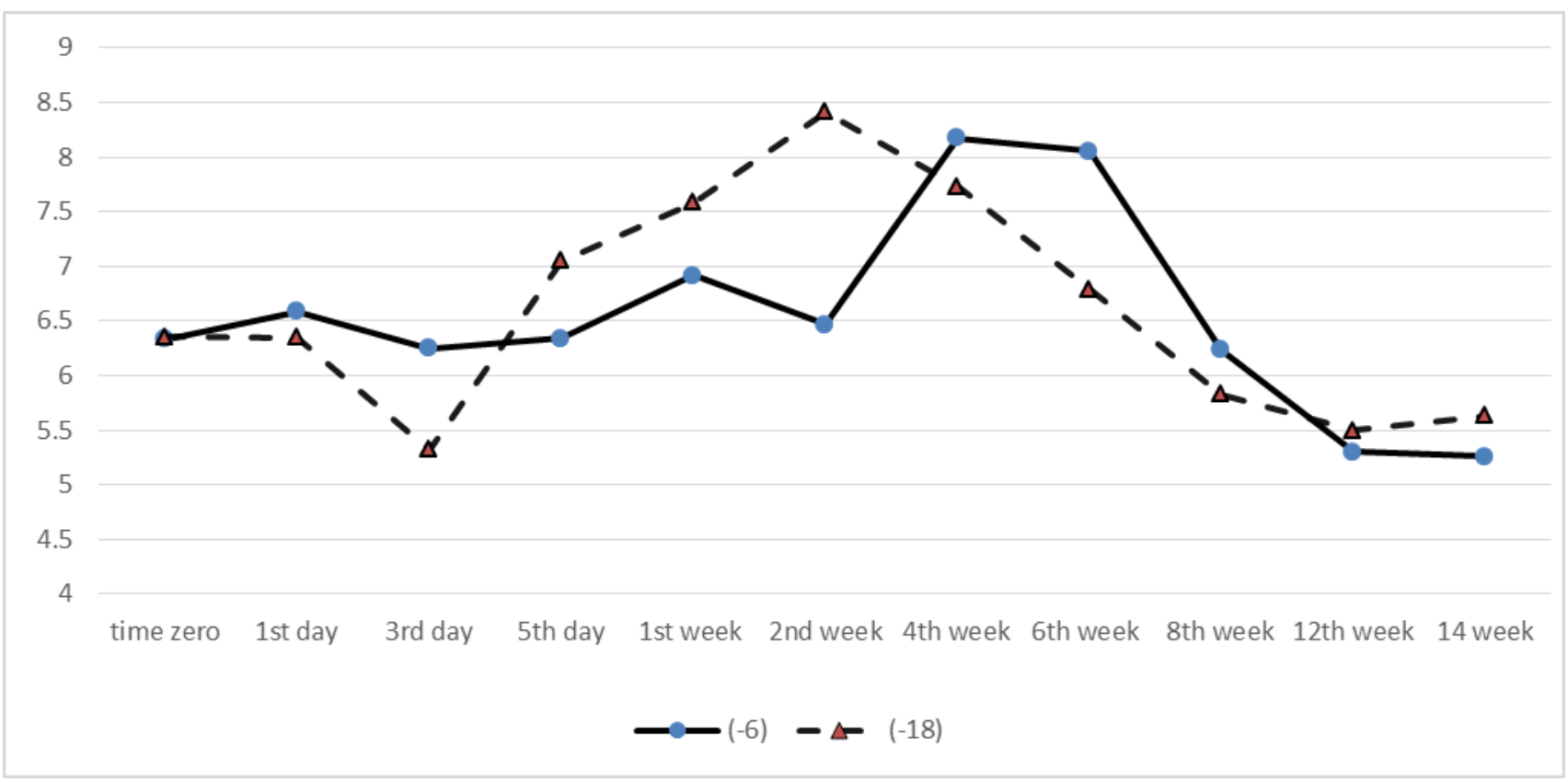

Fig 5: Survival of $Y$. enterocolitica in ice cream

There are significant differences $(\mathrm{P}<0.05)$ between means in the $2^{\text {nd }}$ week.

\section{DISCUSSION}

The presence of Yersinia enterocolitica in milk and its ability to survive at low temperatures during refrigeration and freezing storage is a public health concern in the dairy industry. (Champagene $\boldsymbol{e t}$ al. 2014). So, the need to detect the prevalence of Yersinia enterocolitica in cheese and ice cream becomes our study's goal.

According to the results of the culture method that were recorded in Table 2, the incidence of Yersinia spp. in the examined samples of cheese was $20 \%$, this result was nearly similar to the results recorded by Rahimi et al. (2014), who could isolate Yersinia spp. from $23.3 \%$ of the tested cheese samples which was the highest incidence among all recorded results of the examined milk products. On the other hand, Hamama et al. (1992) could isolate Yersinia spp. from $14.3 \%$ of the analyzed traditional fresh cheese samples (Jben).

As recorded in Table 2, the prevalence of $Y$. enterocolilica in the examined cheese samples was $17.5 \%, 7$ out of the isolated Yersinia spp. Strains were identified biochemically as $Y$. enterocolitica, and one strain was $Y$. frenderikenii (2.5\%). This incidence of $Y$. enterocolitica in cheese was lower than the obtained result by Salah et al. (2012), who could detect the organism in $24.4 \%$ of the tested samples of cheese, but lower results were recorded by Abd El-Aal and Atta (2009); El-Malt (2009); Hanafian and Khani ( (2012); Ali et al. (2015) who could isolate the organism from $8,6,10.5$ and $4 \%$ of the examined cheese samples, respectively.
Regarding the examined ice cream samples, the incidence of Yersinia spp. in this study was 30\%, which was higher than the reported results by Rahimi et al. (2014), who could detect Yersinia spp in a percentage of $5.7 \%$. Ten out of the isolated strains of Yersinia spp. from ice cream were identified as $Y$. enterocolitica with a percentage of $25 \%$, while $Y$. frenderikenii and $Y$. intermedia were found in $2.5 \%$ of the tested ice cream samples for each, as in Table 2.

All the biochemically identified $Y$. enterocolitica strains were subjected to molecular detection of the 16S rRNA gene of $Y$. enterocolitica. The result illustrated in Table 3, revealed that 42.8 and $60.0 \%$ of the isolated strains from cheese and ice cream were confirmed as $Y$. enterocolitica, respectively. Hence, the incidence of $Y$. enterocolitia in cheese and ice cream based on PCR result was 7.5 and $15 \%$, respectively, according to the data represented in Table 3 and figure 1. Rahimi et al. (2014); Ali and AlSamari (2020) demonstrated lower results for the detection of $Y$. enterocolitica by using PCR than the culture method's recorded result, and this is in agreement with our study. Still, they recorded lower incidence with a percentage of 7.77 and $7 \%$ for culture method and 6.6 and $4.5 \%$ for PCR respectively, this difference between the reported results by cultural methods and PCR may be due to that biochemical tests are complex and give unreliable results (Neubauer $\boldsymbol{e t}$ al., 2001; Vishnubhatla et al., 2001) and some of Y. enterocolitica biochemical activities are temperaturedependent above and below $30^{\circ} \mathrm{C}$, and so misidentifications can be found (Manafi and Holzhammer, 1994). 
Concerning the recovery rate of $Y$. enterocolitica from ice cream, the recorded results by Elsherbini et al. (1999) were in agreement with our results, where they could isolate $Y$. enterocolitica in a percentage of $24.5 \%$, while, Warke et al. (2000); Yucel and Ulusoy (2006) recorded a higher prevalence of $Y$. enterocolitica and the rate of isolation was 40.3 and $35.7 \%$. On the contrary, a lower incidence was recorded by Norma and Ana (2000); Khalifa et al. (2007); Ye et al. (2014); Rahimi et al. (2014) where, they could isolate $Y$. enterocolitica in a percentage of $2.5,10,5$ and $2.85 \%$ respectively.

It is worthwhile to state that, isolation of $Y$. enterocolitica from cheese and ice cream in high percentage to some extent may be attributed to using unpasteurized milk and processing of these products under unsanitary conditions, where contamination of the products may occur from human handlers or the environment. Also, the storage of these products at low temperatures supports the growth of the organism.

The results of bio- typing and serotyping as given in Table 4 revealed that, 8 out of the confirmed $Y$. enterocolitica strains proved to be pathogenic since they were belonged to biotypes 2, 4 and 5 and one strain was bio- typed 1A. On the other hand, O: 3 was the most prevalent serotype in cheese $(66.66 \%)$ and ice cream (50\%). In addition, serotype O: 8 was found in a frequency of $33.3 \%$ in cheese, while, serotypes O: 8 , O: 4 and O: 5 were found in a percentage of $16.66 \%$ of the isolated strains from ice cream.

The isolated pathogenic strains detected by bio- typing and serotyping and belonged to biotype 2. 4 and 5 were examined to detect ail and yst genes by PCR technique. As observed in Figures $2 \& 3$, all the tested strains exhibited ail gene, but the $y$ st gene failed to be detected. Obviously, detection of the pathogenic strains based on bio-typing was in agreement with the PCR assay result, where all detected pathogenic strains by bio- typing were positive for the targeting chromosomal ail gene.

The instability of the virulence plasmid gene (pYV), which can be lost under alkaline $\mathrm{pH}$ (Thoerner et al. 2003; Myers et al. 2006), promoted us to choose the chromosomal genes for detecting the virulent strains. PCR assay can detect the pathogenic strains rapidly and with a higher degree of accuracy with the culture method, but this assay is very expensive when applied to the samples directly. Although the PCR technique is highly sensitive and effective in the case of pure isolates, when applied to the samples directly, its sensitivity is reduced due to the complexity of the sample composition and the low count of the target organism. So, enrichment of the sample before PCR is applied to increase the count and help in the detection of the bacterial cells (Lantz et al., 1998 and Fredriksoon- Ahomaa and Korkeala, 2003).

Cheese is one of the most popular foods, and it is a part of the stable diet to the majority of the consumer in the world. The largest proportion of Damietta cheese is manufactured from raw milk. Hence, the numerous opportunities for cheese contamination with pathogenic $Y$. enterocolitica strain during manufacture. In addition, refrigeration storage of cheese supports the growth of this pathogen due to its psychrotrophic nature. Therefore, the growth patterns of $Y$. enterocolitica in Damietta cheese during storage were important in our study to determine the optimum condition that may be applied to ensure microbial safety.

The recorded data in Table 5 and 6 represented the effect of refrigeration storage on the viability of $Y$. enterocolitica in cheese during refrigeration storage, the generation time (GT) dependence of temperature for multiplication of $Y$. enterocolitica at room temperature $\left(30 \pm 2^{\circ} \mathrm{C}\right)$ to refrigeration $\left(4 \pm 2^{\circ} \mathrm{C}\right)$ required about 24 hours for growth from $5.8 \pm 75 \mathrm{log}$ $\mathrm{cfu} / \mathrm{g}$ to $6.6 \pm 0.4 \log \mathrm{cfu} / \mathrm{g}$, which is lesser than required by $Y$. enterocolitica isolates to reach $6.5 \pm$ $0.85 \log \mathrm{cfu} / \mathrm{g}$ and these results was in agreement with that recorded by (Amin and Drowghon 1978) who reported $16.8 \mathrm{~h}$ to $25.9 \mathrm{~h}$ (GT) of $Y$. enterocolitica in skim milk stored at $4^{\circ} \mathrm{C}$ during refrigeration storage. Then, there was an increase in the organism's count on the $2^{\text {nd }}$ week of the experiment in refrigeration and room temperature storage to $7.4 \pm 0.63 \mathrm{log} \mathrm{cfu} / \mathrm{g}$ and $8.2 \pm 0.68 \log \mathrm{cfu} / \mathrm{g}$, respectively. Then there was a state of lower growth and multiplication of $Y$. enterocolitica in refrigerating cheese samples, which was in agreement with Champagene et al. (2014), who stated that at low temperature, the growth curve has a long lag phase and slower logarithmic phase, while, Stern et al. 1980 recorded a four days lag phase followed by linear $Y$. enterocolitica population growth in milk held at $3^{\circ} \mathrm{C}$ for 20 days.

An increase in the growth and survival of $Y$. enterocolitica was shown on the $8^{\text {th }}$ week and the mean value of its count was $9.9 \pm 0.16 \log \mathrm{cfu} / \mathrm{g}$. and $9.6 \pm$ $0.41 \log \mathrm{cfu} / \mathrm{g}$ in refrigeration and at room temperature storage, respectively. Then, gradual decline in the microbial density of $Y$. enterocolitica from the $14^{\text {th }}$ week to the end of the experiment on the $18^{\text {th }}$ week in which the mean value of the organism stored in refrigerator and room temperature was $7.4 \pm 0.5 \mathrm{log}$ $\mathrm{cfu} / \mathrm{g}$. and $6.9 \pm 0.16 \mathrm{log} \mathrm{cfu} / \mathrm{g}$., respectively. The significant difference was recorded at the $3^{\text {rd }}$ week between cheese storage at $30 \pm 2^{\circ} \mathrm{C}$ and $4 \pm 2^{\circ} \mathrm{C}$ (Fig.4). 
The behavior of $Y$. enterocolitica recorded by Abdollahi and Hanafian 2015 showed an intensively increase in the count during the first day. The growth was consistent to some extent from the $1^{\text {st }}$ to $5^{\text {th }}$ days. Its population was declined from the $5^{\text {th }}$ to the $60^{\text {th }}$ day. The decreasing percentage during storage at $25^{\circ} \mathrm{C}$ is higher than that reported for storage at $8^{\circ} \mathrm{C}$, which was recorded as more favorable for the organism's growth. On the other hand, Otero et al. (2010) found no significant changes in the count of $Y$. enterocolitica during the first two weeks of cheese storage at $4^{\circ} \mathrm{C}$; then, the count starts to decrease not be detected on the $45^{\text {th }}$ day. While at $22^{\circ} \mathrm{C}$, the bacterial population was somewhat stable until the $5^{\text {th }}$ day, the count declined and could not be isolated on the $45^{\text {th }}$ day. Hanafian and Khani (2012) recorded survival of $Y$. enterocolitica for a long time) could not be detected in the $4^{\text {th }}$ month. Chenyang et al. (2020) attributed the prolonged survival of $Y$. enterocolitica at refrigeration storage at $4^{\circ} \mathrm{C}$ to the induction of cold-shock genes, demonstrating its ability to adapt to cold stress.

The survival of $Y$. enterocolitica in our study both at $4 \pm 2^{\circ} \mathrm{C}$ and at room temperature $\left(30 \pm 2^{\circ} \mathrm{C}\right)$ revealed a potential health hazard for the consumers, especially in the $8^{\text {th }}, 10^{\text {th }}$ and $14^{\text {th }}$ weeks where the count of $Y$. enterocolitica was higher than $\left(10^{9} \mathrm{cfu} / \mathrm{g}\right.$. $)$ the infective dose recorded by Doyle (1990). This may be attributed to the low percentage of salt (3\%) used in cheese manufacture and no addition of probiotic bacteria during cheese manufacture in our research., So, an alternative method to decrease the population of $Y$. enterocolitica in cheese during storage other than the temperature factor may be used, where, the differences in the environmental factors of cheese in terms of salt percentage, $\mathrm{pH}$, and lactic acid starter are the main factors affecting the viability of $Y$. enterocolitica (Abdollahi and Hanafian, 2015).

Preservation of food is used to prevent or retard microorganisms' growth to extend its shelf-life and prevent the risk of infection. Freezing is one of these methods that is used in food preservation, especially ice cream. Because ice cream may be contaminated during processing, handling, transportation, and storage, it is incriminated as a source of infection with a pathogenic bacteria that can multiply at low temperatures as $Y$. enterocolitica. So, we aimed to study the viability of $Y$. enterocolitica in ice cream during freezing storage at $-6 \pm 2^{\circ} \mathrm{C}$ and $-18 \pm$ $2^{\circ} \mathrm{C}$.

Comparing the behavioral patterns of $Y$. enterocolitica growth in ice cream during freezing storage at $-6 \pm 2{ }^{\circ} \mathrm{C}$ and $-18 \pm 2{ }^{\circ} \mathrm{C}$ revealed that the generation time (GT) for $Y$. enterocolitica multiplication at $30^{\circ} \mathrm{C}$ after manufacturing to $-6 \pm 2{ }^{\circ} \mathrm{C}$ storage required seven days to slight increase from a mean value of count $6.3 \pm 0.26 \mathrm{log} \mathrm{cfu} / \mathrm{g}$. to $6.9 \pm 0.16$ $\log \mathrm{cfu} / \mathrm{g}$. as recorded in Table 7 . While GT. at $30^{\circ} \mathrm{C}$ to $-18 \pm 2{ }^{\circ} \mathrm{C}$ required only five days to reach a nearly similar count from $6.4 \pm 0.43$ to $7 \pm 0.48 \mathrm{cfu} / \mathrm{g}$ (Table 8 ) and this reduction in replication during the first days of the experiment may be attributed to the presence of coliform bacteria inhibited the development of $Y$. enterocolitica in ice cream (Slavchev, 1986). As reported in Table 8, the highest increasing percentage was noted in the $4^{\text {th }}$ week with a mean value of $8.2 \pm$ $0.46 \log \mathrm{cfu} / \mathrm{g}$. and from this time to the end of the experiment, there was a decrease in the count, where the mean value of the organism was declined to 5.5, 5.2 and $5 \log \mathrm{cfu} / \mathrm{g}$ in the $16^{\text {th }}$ week with a mean value of $5.3 \pm 0.26 \log \mathrm{cfu} / \mathrm{g}$.

It is obvious from the previously noted data that the growth pattern of Y.enterocolitica was unevenly changed from increasing to decreasing, with active viability and survival of the organism in inoculated ice cream by Y.enterocolitica during freezing as recorded by Slavchev, 1986, who also stated that this survival recorded to be dependent on the count of the inoculated $Y$. enterocolitica to ice cream as inoculation of $100 \mathrm{cell} / \mathrm{cu} \mathrm{cm}$ remain viable up to the day 90 and the survival period and viability 1000 cell/cu cm reach to the $8^{\text {th }}$ month with showing a reduction in the count after the $6^{\text {th }}$ month.

The data illustrated in Table 8 revealed a high increasing percentage from the $3^{\text {rd }}$ day to the $2^{\text {nd }}$ week. The reduction in the count of $Y$. enterocolitica started from the second week to the $8^{\text {th }}$ week and still stable to the end of this treatment with a mean value of $5.6 \pm$ $0.39 \log \mathrm{cfu} / \mathrm{g}$, which nearly agrees with the results recorded by Norma and Ana (2000) during studying the behavioral pattern of $Y$. enterocolitica at $-18{ }^{\circ} \mathrm{C}$ who recorded an increase in the bacterial density of the organism from time zero to the first month, then, the count return to decrease during the second month. The cell population remains stable to some extent for 16 months. Also, they attributed this to the low $\mathrm{pH}$ of ice cream to (4- 5), which decrease the viability of the organism, Since they failed to isolate the organism in the $5^{\text {th }}$ month from ice cream with low $\mathrm{pH}$, while Abd El-Fatah et al. (2015) reported low reduction rate in the count of Y.enterocolitica for two months during freezing storage at $-20^{\circ} \mathrm{C}$. Also, Uzunlu et al. (2004) recorded a similar decrease in $Y$. enterocolitica from 6.08 to $5.66 \log \mathrm{cfu} / \mathrm{g}$. During two months, when stored at $-20^{\circ} \mathrm{C}$ with stable growth rate and low rate of decline in the organism viability.

The behavioral patterns of $Y$. enterocolitica during freezing storage of ice cream were unstable during the 
first six weeks, but the significant differences between the effect of freezing $-6 \pm 2{ }^{\circ} \mathrm{C}$ and $-18 \pm 22^{\circ} \mathrm{C}$ was recorded in the $2^{\text {nd }}$ week with $\mathrm{P}$-value $<0.05$ where the reported mean value of the bacterial density at $-6 \pm 2$ ${ }^{\circ} \mathrm{C}$ was lower than storage $-18 \pm 2{ }^{\circ} \mathrm{C}$ by $1.94 \log \mathrm{cfu} /$ $\mathrm{gm}$ and the rate of reduction in the number of viable cells at $-18 \pm 2^{\circ} \mathrm{C}$ from the fourth week up to the end of the experiment was higher than that recorded at $-6 \pm$ $2^{\circ} \mathrm{C}$ as represented in Fig. 2.

The viability of the organism in ice cream due to the existence of protein and fat, which have a protective effect on $Y$. enterocolitica (Roora et al., 1992) also the adjustment of fatty acids in the lipid bilayer membranes making shorter chain and involvement of unsaturated chains was the way to prevent fat solidification and breakage of the membrane of the microorganism. (Jay 1996; Gounot 1991).

\section{CONCLUSION}

It can be concluded that, the results of our study confirmed the probability of cheese and ice cream contamination with the pathogenic strains of $Y$. enterocolitica and this may be attributed to the unsanitary conditions during milking, processing and storage and using unpasteurized milk for manufacturing these products. On the other hand, its survival in cheese and ice cream for a long time during refrigeration and freezing temperature render it of special public health significance. Therefore, preventive measures must be applied during manufacture and during storage up to the consumption to decrease the chance of contamination. Also, studies and trials should be carried out in the future to affect its viability by adding different concentrations of salt and probiotics in cheese and decreasing the $\mathrm{pH}$ of ice cream.

\section{Declaration of Competing interest}

On behalf of all authors, I hereby declare that no conflict of interest may interfere with the publication of the manuscript.

\section{REFERENCES}

ABD EL- FATAH, EMAN, N., AMER, I. H., ELSAYED, M. S. AND MANSOUR, M. A. H. .2015 . Assessment of the effect of freezing on the survival of some pathogenic bacteria in ice cream. J. Global. Biosci, 4(7) 2873-2877.

ABD EL-AAL, S. F. A. AND ATTA, M. A-H. B. .2009. Occurrence of listeria and Yersinia spp. in milk and some milk products. Assiut Vet. Med. J., 55 (123): 45- 59.

ABDOLLAH, ELHAM AND HANAFIAN, SHARMA .2015. Behavior of
Y. enterocolitica in UF white cheese: impact of different storage temperature on various strains .J. Food Safety, 36(2): 247- 253.

ABOU EL- MAKAREM, H. S. M. .2009. Plasmid Profile for several pathogenic microorganisms strains isolated from market kareish cheese. M. V. Sc. Thesis, Faculty of Vet. Med., Alexandria.

ALI, AMANY, M., ATTIAH, S. A. AND ALY, SALWA, A. .2015. Incidence of $Y$.enterocolitica in milk and some milk products. Inl. J. Adv. Biol. Res., 5(4): 285288.

ALI, MAY, M. AND AL-SAMARI, F. R. Identification and characterization of virulent $Y$. enterocolitica in locally produced soft cheese in Iraq. Plant Archives, 20 (2): 6595- 6600.

AMIN, M. AND DRAUGHON, F. A. .1987. Growth characteristic of Yersinia enterocolitica in Pasteurized skim milk, J. Food Port. , 50; 275-281.

ANNA, F. AND JORDI, V. .2012. $Y$. enterocolitica: Pathogenesis, virulence and antimicrobial resistance. Enfermeda des Ifecciosas y microbiologia, 30 (1): 24 32.

BAHGAT, N. AND VIRDI, J. S. .2007. Distribution of virulence-associated genes in $Y$. enterocolitica biovar 1 A correlates with clonal groups and not the source of isolation FEMS Microbiol., 266 (2): 177- 183.

BOLTON, D. J., IVORY, C. AND MACDOWELL, D. .2013. A small study on Y. enterocolitica in pigs from birth to carcasses and characterization of porcine and human strains. Food Control, 33: 521- 524.

BOTTONE, E. J. .1997. $Y$. enterocolitica: the charisma continues. Clin. Microbiol. Rev., 10: 257- 276.

CHAMPAGNE, PC, LAING R. R.; ROY D.; MAFU A. A.; GIFFITHS W. M. AND WHITE C. .1914. Psychrotrophs in dairy products: Their effects and their control. Food Sci.Nutr 34(1):1-30

CHENYANG L., MURUGAIYAN J., THOMAS C., ALTER T. AND RIEDEL C. .2020. Isolate Specific Cold Response of Yersinia enterocolitica in Transcriptional. Front. Microbiol. 10: 3037-3053.

DOYLE, M. E. .1990. Pathogenic E. coli, Y. enterocolitica and Vibrio parahaemolyticus. Lancet 336, 1111.

EL-MALT, LAILA, M. .2009. Occurrence of Coliformis and Yersinia spp. in raw milk and kareish cheese in Quena Governorate, 37(3): 32.

EL- SHERBINI, M., AL-AGILI, S., EL-JALI, H., ABOSHKIWA, M. AND KOHA, M. .1999. Isolation of $Y$. enterocolitica from cases of acute appendicitis and ice cream. East Mediterr. Health J., 5(1): 130- 135.

FDA/ CFSAN/ BAM .2007. $Y$. enterocolitica Bacteriological Analytical Manual online chp.8. US Food and Drug Administration Center for Food Safety and Applied Nutrition. Weagant, S.D. and Feng, $\quad$ P., http://www.cfsan.fda.gov/ ebam/bam.8.html,2001,up dat2007.

FREDRIKSSON- AHOMAA, M. AND KORKEALA .2003. Low occurrence of pathogenic $Y$. enterocolitica in clinical food environmental samples: a methodological problem. Clinical Microbid. Reviews, 16 (2): 220- 229. 
FREDRIKSSON- AHOMDA, M., LINDRSTROM, M. AND KORKEATA, H. .2010. $Y$. enterocolitica and Y. pseudotuberculosis in Juneau, V. K. and Sofos, N. J. (Eds), Pathogen and Toxins in Foods Challenger and Intervention. ASM press. Washington, D. C., 164- 180.

GRAM, L., RAVN, L., RASCH, M., BRUH, J. B., CHRISTENSEN, A. B. AND GIVSKOV, M. .2002. Food spoilage interactions between food spoilage bacteria. Int. J. Food Microbiol., 78: 79- 97.

GOUNOT, A. M. .1991. Bacterial life at low temperatures: physiology aspects and biotechnological implication. J. Appl. Bacteriol., 71: 386- 397.

HAMAMA, A., EL-MARRAKCHI AND OTHMANI, F. 1992. Occurrence of Yersinia enterocolitica in milk and dairy milk products in Morocco. Inter. J. Food Microbiol., 16: 69-77

HANAFIAN, S. AND KHANI, S. .2012. Fate of $Y$. enterocolitica during manufacture, ripening and storage of Lighvan cheese. Int. J. Food Microbiol., 156:141-146.

HANAFIAN, S. AND KHANI, S. .2012. Prevalence of virulent $Y$. enterocolitica and $Y$. pseudoluberculosis in bulk raw milk and retail cheese in northern-west of Iran. Int. J. Food. Microbiol., 155: 89- 92.

HARAKEH, E. SALEH, I., BARBOUR, E. AND SHAIB, H. .2012. Highly resistant $Y$.enterocolitica isolated from dairy-based foods in Lebanon. Int. Arabic J. Antimicrob. Agents, 2(1):

HARTING, M. AND GERIGK, K. .1991. Yersinia in effluents from food processing industry. Rev. Sci. Tech., 10: 799- 807.

ILIEV, M. AND NAJDENSKI, H. .2008. Monitoring of plasmid dissociation and pathogenic potential among $Y$. enterocolitica and $Y$. pseudotuberculosis during storage of refrigerated pork meet. Anna's of Microbiol., 58 (4): 623- 632.

JAY, J. M. .1996. Modern food microbiol. New York, Champan\& Hall.

KHALIFA, NASHWA, O., ABOU ELROOS, NAHLA, A. AND SHARAF, EMAN, M. .2007. Public health importance of $Y$. enterocolitica in ice cream peddler in Kaliobia Governorate. Alex. J. Vet. Sci., 26 (1): 51- 54.

LANTZ, P. G., KNUTTSSONA, R., BLIXTB, Y., ABU AL-SOUDA, W. BORCH, E. AND RADOSTORM, P. .1998. Detection of pathogenic $Y$. enterocolitica in enrichment media and pork by a multiplex PCR: A study of sample preparation and PCR- inhibitory components. Int. J. Food Microbiol., 45: 93- 105.

MACFADDIN, J. F. $\mathbf{. 2 0 0 0}$. Biochemical tests for identification medical bacteria. Warery Press Inc, Baltimore, Md. 21202 USA.

MANAFI, M., AND HOLZHAMMER, E. $\mathbf{. 1 9 9 4 .}$ Comparison of the Vitek, API 20E and Gene trak® systems for the identification of $Y$. enterocolitica. Letters in Appl. Microbiol., 18: 90- 92.

MYERS, K. M., GABA, J. AND AL-KHALDI, S. F. .2006. Molecular identification of $Y$. enterocolitica isolated from pasteurized whole milk using DNA Microarray chip hybridization. Mol. Cell. Probes, 20: 71- 80.
NEUBAUER, H., SPRAGUE, L. D., SCHOLZ, H. AND HENSEL, A. .2001. Diagnosis of $Y$. enterocolitica infections: a review on classical identification techniques and new molecular biological methods. Berliner und Munchenertierarztliche Wochenschrift, $114(1-2), 1-7$

NORMA, B. P. AND ANA, M. S. .2000. Isolation of Y.enterocolitica in ice cream at different $\mathrm{pH}$ values Stored at $-18 \pm 2^{\circ} \mathrm{C}$. Brazilian J. Microbiol., 31: 174177.

NUSRAT, S., DEVANG, S. AND SUFIAN, F. .2009. Detection of $Y$. enterocolitica in alfalfa, Mung Bean, Cilantro and mameysapote (Pouteria sapota). Food Matrices using DNA Microarray chip hybridization. Curr. Microbiol., 59: 233- 239.

OTERO.V. L., ESTRAD, C. L., FAVIER, G. I., VELAZQUEZ, L., ESCUDERO, MARIA, E. AND SLEFANINI DE GUZMA, ANA MARIA.2010. Detection and survival of $Y$. enterocolitica in goat cheese produced in San Luis, Argentina. J. Food Safely, 30(4): 982- 995.

RAHIMI, E., SEPEHRI, SARA, DEHKODI, F. S., SHAYGAN, SHIMA AND MOMTAZ, H. .2014. Prevalence of Yersinia spp. in traditional and commercial dairy products is Isfahan Province, Iran. Jundishapur J. Microbiol., 7 (4): 249- 255.

RAKESH, K. .2007. Advances in Thermal and NonThermal Food Preservation (Aseptic Processing) (pp.43). $1^{\text {st }}$ ed. Edited by Black Well Publishing Ltd, Oxford, UK.

ROORA, S., BUDU- AMOAKO, E., ABLETT, R. F.AND SMITH, J. .1992. Effect of high temp- short-time pasteurization, freezing and thawing and constant freezing on the survival of $Y$. enterocolitica in milk. J. Food Prot., 55: 803- 805.

SCHRIEFER, M. E. AND PETERSEN, J. M. .2011. Yersinia. In: Versalovic, J., Caroll, K. C., Funke, G., Jorgensen, J. H., Landry, M. L. and Warnock, D. W., Ed. Manual of Clinical Microbiology. $10^{\text {th }}$ ed. Washington: American Society for Microbiology Press 627-238.

SEVERGNINI, M., CREMONESI, P., CONSOLANDI, C., DE BELLIS, G. AND CASTIGLIONI, B. .2011. Advances in DNA microarray technology for the detection of food-borne pathogens. Food Bioprocess Tech., 4 : 936- 953.

SHURNIK, M. AND TOIVONEN, S. .2011. Identification of distinct lipopolysacharid patterns among Y.enterocolitica and Y.enterocolitica like bacteria. Biochemistry (MOSC), 76- (7): 823- 831.

SLAVCHEVE, G. .1986. Development and survival of Y enterocolitica in pasteurized milk and ice cream Vet. Med. Nauki., 23(6):77-85.

STERN, N.J., PIERSON, M. D. , AND KOTULA, A. W. .1980. Growth and competitive nature of Yersinia enterocolitica in whole milk, J. Food Sci., 45; 64-70.

TENNAT, S.; GRANT, T. AND BROWNE, R. .2003. Pathogenicity of Y. enterocolitica biotype 1A. FEMS Immunol. Med. Microbiol., 38: 127-137.

THOERNER, P., BIN KINGOMBE, C. I., BOGLISLUBER, K., BISSIGCHOISAT, B., WASSENAAR, T. M., FREY, J. AND JEMMI, T. .2003. PCR detection of virulence genes in $Y$. 
enterocolitica and $Y$. pseudoluberculosis and investigation of virulence gene distribution. Appl. Environ. Microil., 69: 1810- 1816.

UZUNLU, S., YILDIRIM, I. AND DEMIR, M. .2004. Survival characteristics of some pathogenic bacteria in vanilla ice cream at different storage periods. Turk. Mikobiyol. Cem. Derg., 34:195-199.

VAZLEROVA, M. AND STEINHAUSEROVA, I. .2006. The comparison of the methods for identification of pathogenic serotypes and biotypes of $Y$. enterocolitica: microbiological methods and PCR. Czech J. Food Sci., 24: 217- 222.

VISHNUBHATLA, A., OBERST, R. D., FUNG, D. Y. C., WONGLUMSOM, W., HAYS. M. P., AND NAGARAJA, T. G. .2001. Evaluation of a 52 nuclease (TaqMan) assay for the detection of virulent strains of $Y$. enterocolitica in raw meat and tofu samples. J. Food Prot., 64: 355-360.

WANNET, W. J., REESSINK, M., BRUNINGS, H. A., MAAS, H. M. .2001. Detection of pathogenic $Y$. enterocolitica by a rapid and sensitive duplex PCR assay. J. Clin. Microbiol, 39(12):4483- 6.

WARKE, R., KAMAT, A., KAMAT, M. AND THOMAS, P. .2000. Incidence of pathogenic psychotrophes in ice cream sold in some retail outlets in Mumbai, India. Food Cont., 11: 77- 83.

YE, Y. W., LING, N., HAN, Y. J. AND WUT, Q. P. .2014. Detection and prevalence of pathogenic $Y$. enterocolitica in refrigerated and frozen dairy products by duplex PCR and dot hybridization targeting the virf and ail genes. J. Dairy Sci., 97: 6785-6791.

YUCEL, M. N. AND ULUSOY, H. .2006. A Turkey Survey of hygienic indicator bacteria and $Y$. enterocolitica in raw milk and cheese sample. Food contr., 17: 383- 388.
How to cite this article:

Salwa S. Thabet and Manal H.Thabet, 2021.

Viability of The Isolated Yersinia Enterocolitica Strains from Damietta Cheese and Ice Cream at Different Refrigeration and Freezing Temperatures . Journal of Applied Veterinary Sciences, 6(2): 1 - 14.

DOI: https://dx.doi.org/10.21608/javs.2021.154573 